\title{
INVESTIGATING THE IMPACT OF GOVERNMENTAL GOVERNANCE ON MEGAPROJECT PERFORMANCE: EVIDENCE FROM CHINA
}

\author{
Zhao ZHAI ${ }^{1}$, Ming SHAN ${ }^{2}$, Yun $\mathrm{LE}^{3}$ \\ ${ }^{1}$ School of Traffic \& Transportation Engineering, Changsha University of Science \& \\ Technology, Changsha, China \\ ${ }^{2}$ School of Civil Engineering, Central South University, Changsha, China \\ ${ }^{3}$ School of Economics and Management, Research Institute of Complex Engineering \& \\ Management, Tongji University, Shanghai, China
}

Received 15 March 2019; accepted 15 September 2019

\begin{abstract}
Governmental governance is an emerging concept in the area of governance and is critical to the success of megaprojects. The aims of this study are to investigate the impact of governmental governance on megaproject performance and to identify the most critical component of governmental governance. To achieve these goals, a conceptual framework of governmental governance and a comprehensive framework of megaproject performance were established first, followed by proposing a research hypothesis that governmental governance could contribute to megaproject performance. To test the hypothesis, data collected by a questionnaire administered to 239 professionals were analyzed using partial least squares structural equation modelling. Results showed that governmental governance could contribute to megaproject performance significantly. It also reported that "public monitoring and scrutiny" was the most critical latent variable of governmental governance on megaproject performance, followed by "systemic risk management," "regulatory oversight," "construction of clean government," "strategic planning," and "institutional design." This study has contributed to the body of knowledge of governmental governance by investigating its impact on megaproject performance. The findings from this study are useful to the industry as well, because they can enhance practitioners' understanding of governmental governance, which could help them improve their management of megaprojects eventually.
\end{abstract}

Keywords: megaprojects, governmental governance, project governance, performance, structural equation modelling, China.

JEL Classification: G38, H19, L74.

\section{Introduction}

Over the past decades megaprojects have been increasingly built worldwide because they are crucial to economic growth and social prosperity (Hu et al., 2016; Söderlund et al., 2017).

*Corresponding author. E-mail: ming.shan@csu.edu.cn

This is an Open Access article distributed under the terms of the Creative Commons Attribution License (http://creativecommons. org/licenses/by/4.0/), which permits unrestricted use, distribution, and reproduction in any medium, provided the original author and source are credited. 
Despite the prosperity of megaprojects, it is a truism that megaprojects are confronted with various problems such as extreme technical and social complexity, poor delivery, poor performance of construction safety, and severe impact on society, human conditions, and environment (Callegari et al., 2018; Flyvbjerg, 2011). To address these problems, project governance, an approach that is beyond management and dealing with complexity, has been widely used in managing megaprojects, trying to ensure the success of megaprojects (Müller \& Lecoeuvre, 2014; Pitsis et al., 2014; van Marrewijk \& Smits, 2016).

Project governance refers to a management mechanism that defines objectives for some project, devises the relevant means to achieve those objectives, and presents how project performance is monitored (Müller \& Lecoeuvre, 2014). Good project governance can balance the control and trust between project stakeholders (Zwikael \& Smyrk, 2015), enable an effective management process (ul Musawir et al., 2017), thereby improving project performance (OECD, 2017; Too \& Weaver, 2014; Joslin \& Müller, 2016). When it comes to the realm of megaprojects, project governance is usually extended to the institutional level and macro environment (Morris \& Geraldi, 2011), and refers mainly to the oversight of government in leading and managing megaprojects (Gil \& Lundrigan, 2012). Considering the special role that government has played in managing megaprojects, Zhai et al. (2017) proposed the concept of governmental governance, which is a particular type of management framework that is developed for megaprojects, where government plays a vital role and the top-down management methods featured in administrative power are widely adopted to ensure project success. Furthermore, Ma et al. (2017) developed a megaproject governance framework from the view of "business-government-society", in which government relates the hierarchical governance. Brunet and Aubry (2016) and Cardenas et al. (2017) also examined the concept of governmental governance. They pointed out that the primary goal of implementing governmental governance is to achieve the legitimacy, accountability, efficiency, and resilience of megaprojects.

Recently, governmental governance has been increasingly adopted in managing megaprojects worldwide. For examples, the United States Department of Energy has adopted an alliance network combining government and the public to manage megaprojects in the field of energy (Peterman et al., 2014). Norwegian government established a government-featured hierarchical control regime to manage megaprojects, in which the governance flows from top government agencies down to the project level (Klakegg et al., 2008). In The United Kingdom, government plays a major role in supervising megaprojects. For instance, the Office of Government Commerce will establish guidelines for megaproject implementation; the Major Project Authority needs to report the construction status annually; and the National Audit Office is responsible for reviewing the report (Klakegg et al., 2016). Despite the increasing adoption of governmental governance, few studies have been done to examine the interrelationships between governmental governance and megaproject performance. As a result, this study aims to fill in the knowledge gap by conducting an empirical research to examine the possible interrelationships between governmental governance and megaproject performance.

The research efforts of this study were conducted under the context of China. In China, most megaprojects are led by an organization named headquarter, which is created by the government to coordinate the overall project progress and delivery (Li et al., 2019; Zhai 
et al., 2017). Over the past two decades, private capital has quickly flowed into the megaproject sector of China. However, Chinese governments, including the Central and Local levels, still play a primary role in managing megaprojects of the country. For instance, the Central government is responsible for initiating megaprojects, guiding, and coordinating the implementation of megaprojects at a high level, while the Local government is in charge of the megaproject construction (Chi et al., 2011; Lin et al., 2015). Additionally, the Local government will also help on some pre-construction matters such as acquisition of lands and relocation of the people who are affected by the megaproject construction (Dickson et al., 2016; Haveman et al., 2017). Thus, it can be observed that governmental governance has a widespread adoption in China, making China a good and suitable context to conduct the research. Similar to western countries, governmental involvement in megaprojects has been criticized for offering insufficient support (Bennon et al., 2017), making the megaproject more susceptible to corruption (Locatelli et al., 2017), even reduces the chance of success (Sallinen et al., 2011). However, it has not been able to rule out the possibility that in Chinese cases governmental governance might favorably influence the performance of projects (Ren, 2017; Wang, 2014; Zhu et al., 2018).

To achieve the goal of the research, this paper conducted a comprehensive literature review first. Then, using the information gathered from literature review, this paper established a theoretical framework of governmental governance and a framework of megaproject performance, respectively. After that, a hypothesis that governmental governance can contribute to the performance of megaprojects was suggested. Lastly, the hypothesis was tested using the approach of partial least squares structural equation modelling.

Although there has been considerable research on megaproject governance, for example the adoption of relational governance in the management of megaprojects (Chi et al., 2011), culture-based governance in megaprojects (van Marrewijk \& Smits, 2016), evolutionary organizational governance in megaprojects (Lu et al., 2015), megaproject societal governance (Ma et al., 2017), evolutionary governance in a changing environment and its impact (Li et al., 2018, 2019), few of them looked into governmental governance, let alone the investigation of the interrelationships between governmental governance and megaproject performance. Thus, this study should make contribution to the field of governance research. Besides, as this study presented the experiences learned from the real megaprojects, it should prove to be valuable to industry practitioners, because they can enhance their understandings of governmental governance and thereby improve their management and implementations of megaprojects.

\section{Conceptual framework}

\subsection{Governmental governance in megaproject}

Although the notion of governmental governance is relatively new to megaproject management, it has been widely recognized by considerable studies that government is a powerful stakeholder of megaprojects and has played a critical role in managing such type of projects (Sallinen et al., 2011). For instance, Shiferaw et al. (2012) introduced a project governance framework that was established by the Ethiopian government, and they claimed that the 
active intervention by government is one of the top three most important components of the framework. Sallinen et al. (2013) achieved a similar conclusion that government was the most important stakeholders of megaprojects in the nuclear industry. Gil and Lundrigan (2012) and Aubry et al. (2014) found that appointing a top governance committee with most of the committee members from government is helpful to the successful implementation of megaprojects. Peterman et al. (2014) conducted a series of case studies and found that governments was the best party to coordinate the complicated relationships of the different stakeholders of megaprojects. Grubbauer and Čamprag (2018) further explained the power of coordination runs not only between different levels of government, but also between public and private stakeholders, based on governmental regulation. Li et al. (2019) elaborated a megaproject governance model in a transportation hub project and found higher hierarchical governance led to better project performance. Despite the positive governmental influence on megaprojects, some argue that active governmental involvement may limit project success (Sallinen et al., 2011). Together these studies provide insights into the importance of government in megaprojects.

Partidário and Coutinho (2011) pointed out that the government's strategic planning is the key decision factor in front-end phase of airport projects. Locatelli et al. (2015) investigated 12 large power plants and highlighted that megaprojects must fit in the long-term plan of the government. Similarly, Papke-Shields and Boyer-Wright (2017) claimed that a feasible strategic plan made by governments would be helpful to the implementation of megaprojects, especially to the handling of the unanticipated difficulties in megaprojects. OECD (2017) also highlighted the importance of government's planning in conducting megaprojects and emphasized that establishing a standard plan procedure and having a clear budget al.ocation are extremely important.

Regulatory oversight of megaprojects has been widely discussed by prior studies. Stoney and Krawchenko (2012) pointed out that adequate supervision for megaprojects by government is crucial. A. Toivonen and P. U. Toivonen (2014) examined the potent governance mechanisms in controlling and monitoring megaprojects. Also, a multi-level regulatory system in regard to the multi-level nature of megaprojects benefits the successful project delivery (Biesenthal \& Wilden, 2014; Hu et al. 2018).

$\mathrm{Ng}$ et al. (2012) pointed out that public participation should be allowed by the government throughout the whole project lifecycle, which has been usually ignored yet (Xie et al., 2017). To improve the transparency in managing megaprojects, World Bank (2016)suggested that the government should release important information of megaprojects opportunely and regularly, such as taking the media as a governance mechanism (Bednar, 2012), and establishing agency to audit and assess performance of megaprojects (Klakegg et al., 2016).

As noted in previous studies, lacking mature legislative systems could lead to corruption in megaprojects (Locatelli et al., 2017; Shan et al. 2015a, 2015b). Ming Shan et al. (2015a) suggested that the government should build rules and regulations to improve process transparency to proactively prevent corruption practices both in government officials and construction enterprises. The OECD Integrity Framework for Public Investment (OECD, 2016) proposed a set of measures seeking to safeguard integrity of megaprojects. Locatelli et al. (2017) used Italian high-speed railways to explain the corruption project context and pro- 
vided strategies such as establishing transparent benefit tracking record. Zhang et al. (2017) reported that stricter regulations and relationship between governmental officials and stakeholders should be given priority.

To increase megaprojects' capacity in adapting to disruptive events, OECD (2017) recommended several solutions, including establishing a governmental organization particularly responsible for emergency management, developing a comprehensive plan for risk management, and referring to the past experiences. Similarly, Vahanvati and Mulligan (2017) also suggested that establishing a particular governmental organization responsible for emergency management is a necessity to managing megaproject. The researchers also highlighted that the primary missions of the organization are to establish and prioritize the various actions that will be used to deal with emergency issues.

Based on the literature review presented above, it can be found that government has made considerable efforts in managing megaprojects. These efforts can be categorized into six aspects, including strategic planning (SP), institutional design (ID), regulatory oversight (RO), public monitoring and scrutiny (PMS), construction of clean government (CCG), and systemic risk management (SRM). Thus, a framework of governmental governance was created in this study. Constructs and the relevant observed variables of the framework are shown in Table 1.

Table 1. Proposed framework of governmental governance

\begin{tabular}{|c|c|c|c|}
\hline $\begin{array}{l}\text { Latent } \\
\text { variables }\end{array}$ & Code & Observed variables & Sources \\
\hline \multirow{4}{*}{ 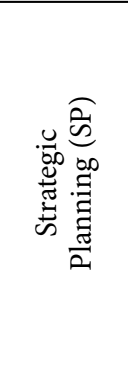 } & SP11 & Presence of a feasible strategic plan & $\begin{array}{l}\text { (OECD, 2017; Papke-Shields \& } \\
\text { Boyer-Wright, 2017; Brookes } \\
\text { and Locatelli, 2015) }\end{array}$ \\
\hline & SP12 & Budget al.ocation to projects in plan & $\begin{array}{l}\text { (OECD, 2017; Peterman et al., } \\
\text { 2014) }\end{array}$ \\
\hline & SP13 & $\begin{array}{l}\text { Dedicated procedure for governing the } \\
\text { project }\end{array}$ & $\begin{array}{l}\text { (OECD, 2017; Zhang et al., } \\
\text { 2017) }\end{array}$ \\
\hline & SP14 & $\begin{array}{l}\text { Formal top governance committees or } \\
\text { platforms to make decision }\end{array}$ & $\begin{array}{l}\text { (OECD, 2017; Aubry et al., } \\
\text { 2014; Bennon et al., 2017) }\end{array}$ \\
\hline \multirow{5}{*}{ 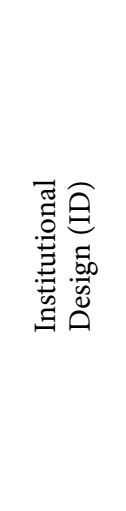 } & ID21 & $\begin{array}{l}\text { A clear set of documents of responsibilities } \\
\text { for all levels of government involved }\end{array}$ & $\begin{array}{l}\text { (OECD, 2017; Peterman et al., } \\
\text { 2014) }\end{array}$ \\
\hline & ID22 & $\begin{array}{l}\text { Formal set of criteria to determine how to } \\
\text { deliver the project }\end{array}$ & $\begin{array}{l}\text { (Lundrigan et al., 2015; OECD, } \\
\text { 2017) }\end{array}$ \\
\hline & ID23 & $\begin{array}{l}\text { Formal co-ordination mechanisms (such as } \\
\text { meetings) are frequently used and produce } \\
\text { clear outputs/outcomes }\end{array}$ & $\begin{array}{l}\text { (Zwikael \& Smyrk, 2015; } \\
\text { OECD, 2017) }\end{array}$ \\
\hline & ID24 & $\begin{array}{l}\text { Informal co-ordination mechanisms (such } \\
\text { as private communications) are frequently } \\
\text { used between government and stakeholders }\end{array}$ & $\begin{array}{l}\text { (Zwikael \& Smyrk, 2015; Chi } \\
\text { et al., 2011; A. Toivonen \& } \\
\text { P. U. Toivonen, 2014) }\end{array}$ \\
\hline & ID25 & $\begin{array}{l}\text { Incentives for high-performance } \\
\text { co-ordination from higher levels of } \\
\text { government }\end{array}$ & $(\mathrm{OECD}, 2017)$ \\
\hline
\end{tabular}


End of Table 1

\begin{tabular}{|c|c|c|c|}
\hline $\begin{array}{c}\text { Latent } \\
\text { variables }\end{array}$ & Code & Observed variables & Sources \\
\hline \multirow{5}{*}{ 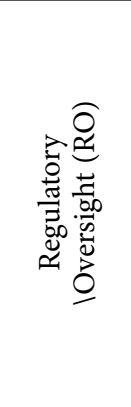 } & $\mathrm{RO} 31$ & $\begin{array}{l}\text { Powerful regulatory mechanism for the } \\
\text { project }\end{array}$ & $\begin{array}{l}\text { (Stoney \& Krawchenko, 2012; } \\
\text { OECD, 2017) }\end{array}$ \\
\hline & $\mathrm{RO} 32$ & $\begin{array}{l}\text { Multi-level regulatory systems for the } \\
\text { project }\end{array}$ & $\begin{array}{l}\text { (Biesenthal \& Wilden, 2014; } \\
\text { OECD, 2017) }\end{array}$ \\
\hline & RO33 & $\begin{array}{l}\text { Independent regulatory authority for the } \\
\text { project }\end{array}$ & $\begin{array}{l}\text { (OECD, 2017; Loch et al., } \\
\text { 2017) }\end{array}$ \\
\hline & $\mathrm{RO} 34$ & $\begin{array}{l}\text { Regulatory authority governs the project } \\
\text { within legal authority }\end{array}$ & $\begin{array}{l}\text { (Stoney and Krawchenko, 2012; } \\
\text { OECD, 2017) }\end{array}$ \\
\hline & RO35 & $\begin{array}{l}\text { Confidence of stakeholders enhanced by } \\
\text { the regulatory mechanisms }\end{array}$ & $(\mathrm{OECD}, 2017)$ \\
\hline \multirow{7}{*}{ 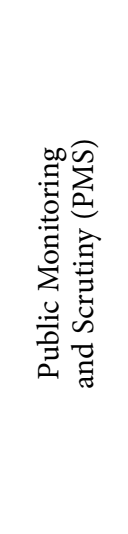 } & PMS41 & Transparent plans for the project & (Ng et al., 2012; OECD, 2017) \\
\hline & PMS42 & $\begin{array}{l}\text { The public can question and give advice in } \\
\text { the planning phase }\end{array}$ & $\begin{array}{l}\text { (Liu et al., 2016; Shi et al., } \\
\text { 2015; Ma et al., 2017; Xie et al., } \\
\text { 2017) }\end{array}$ \\
\hline & PMS43 & $\begin{array}{l}\text { The public can participate in the project in } \\
\text { the construction phase }\end{array}$ & $\begin{array}{l}\text { (Ng et al., 2012; Zhao, 2010; } \\
\text { Xie et al., 2017) }\end{array}$ \\
\hline & PMS44 & $\begin{array}{l}\text { Disclosure of data in an open format on a } \\
\text { dedicated website }\end{array}$ & $\begin{array}{l}\text { (OECD, 2017; Zhang et al., } \\
\text { 2017; Bednar, 2012) }\end{array}$ \\
\hline & PMS45 & $\begin{array}{l}\text { Dedicated procedure for balancing the } \\
\text { interests between public and private parties }\end{array}$ & (OECD, 2017) \\
\hline & PMS46 & Presence of a sound audit system & $\begin{array}{l}\text { (OECD, 2017; Papke-Shields \& } \\
\text { Boyer-Wright, 2017) }\end{array}$ \\
\hline & PMS47 & Disclosure of audit results & (OECD, 2017; Mok et al., 2017) \\
\hline \multirow{4}{*}{ 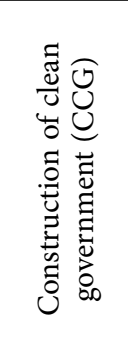 } & CCG51 & $\begin{array}{l}\text { Conflict of interest policies for government } \\
\text { officials }\end{array}$ & $(\mathrm{OECD}, 2017)$ \\
\hline & CCG52 & $\begin{array}{l}\text { Internal system to monitor and identify } \\
\text { irregularities }\end{array}$ & $\begin{array}{l}\text { (Locatelli et al., 2017; OECD, } \\
\text { 2017) }\end{array}$ \\
\hline & CCG53 & $\begin{array}{l}\text { Measures in place to identify the integrity } \\
\text { of all participants }\end{array}$ & (OECD, 2017; Chi et al., 2011) \\
\hline & CCG54 & $\begin{array}{l}\text { Mechanisms to report illegal behaviors } \\
\text { related to megaprojects }\end{array}$ & (OECD, 2017; Bednar, 2012) \\
\hline \multirow{5}{*}{ 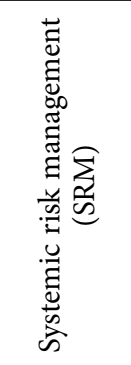 } & SRM61 & $\begin{array}{l}\text { Ability to determine the disaster } \\
\text { prioritization }\end{array}$ & (Vahanvati \& Mulligan, 2017) \\
\hline & SRM62 & $\begin{array}{l}\text { The presence of government agencies } \\
\text { answerable for post-disaster reconstruction }\end{array}$ & $(\mathrm{OECD}, 2017)$ \\
\hline & SRM63 & $\begin{array}{l}\text { The presence of a disaster risk assessment } \\
\text { plan }\end{array}$ & $(\mathrm{OECD}, 2017)$ \\
\hline & SRM64 & The presence of emergency rescue system & (Vahanvati \& Mulligan, 2017) \\
\hline & SRM65 & $\begin{array}{l}\text { Mechanisms in place to learn from past } \\
\text { events }\end{array}$ & (Söderlund et al., 2017) \\
\hline
\end{tabular}




\subsection{Megaproject performance}

It is important and necessary to assess the performance of megaprojects, because project performance assessment is a good strategy to check whether the established objectives of the project are successfully achieved or not (Gil \& Lundrigan, 2012). Recently, an increasing number of studies have started looking into some particular performance of megaprojects. For instance, Flyvbjerg et al. (2003) pointed out the poor performance of megaprojects in terms of economy, environment and public support. Toor and Ogunlana (2010) extend the traditional iron triangle (cost, schedule and quality) to a three-layer performance measurement criteria for megaprojects, including safety, efficiency, effectiveness, satisfaction, and reduced conflicts. Hu et al. (2016) proposed a framework to value the program organization performance of Chinese megaprojects. The proposed framework consists of four types of performance which are cost performance, functionality and quality performance, time performance, and occupational health and safety performance. Xie et al. (2017) assessed the public participation performance of public construction projects. Shenhar and Holzmann (2017) gauged the success of megaprojects using a framework that has dimensions: efficiency, customer, business/financial, and society. Besides traditional objectives, social and environmental concerns in megaprojects have recently received more attention (Ma et al., 2017; Lin et al., 2018). To achieve sustainability, relevant stakeholders including governments are required to take economic, legal, ethical and political responsibilities (Lin et al., 2017; Ghosh et al., 2014). Whether megaprojects objectives are in line with the governmental goals is crucial component of project strategic management, having consequences in various policy arenas (e.g., environmental and social stability maintenance), as well as adapting the project to its complex circumstance (OECD, 2017; Shenhar \& Holzmann, 2017).

Additionally, considerable studies have assessed the performance of generic construction projects. Some of these studies are widely recognized and have been highly cited. For example, Ling et al. (2009) considered project performance measurements as cost, schedule, quality, owner satisfaction, profitability and public satisfaction. In Eriksson and Westerberg (2011)'s study, project performance was evaluated by cost, time, quality, environmental impact, work environment, and innovation. Hanna et al. (2014) provided a mathematical formulation to assess the performance of construction projects on the basis of customer satisfaction, schedule, cost, profit, and communication. Similarly, Chen and Manley (2014) adopted a comprehensive framework consisting of eight dimensions to measure the performance of construction projects. The eight dimensions include cost efficiency, time efficiency, quality, collaboration, innovation, safety, environmental and community impact. Joslin and Müller (2016) showed that project success correlated with project governance significantly. Similar conclusions can be found in Ul Haq et al. (2018) and Ghosh et al. (2014).

In light of the existing literature, this study proposed a comprehensive framework that can assess the performance of megaprojects, which is comprised of three latent variables: primary goals of project (PGP), stakeholder satisfaction (SS) and sustainability of project (SoP). PGP measures the achievement of the major goals of a project, such as the schedule, 
budget, quality, health and safety, and functionality. SS measures the satisfactions of various stakeholders of megaprojects, including the government, the public, as well as the major contracting parties like contractors, consultancies, and suppliers. SoP measures the sustainability of project in terms of environmental sustainability and social sustainability. Details of the three latent variables and the relevant observed variables are shown in Table 2.

Table 2. Proposed framework of megaproject performance

\begin{tabular}{|c|c|c|c|}
\hline $\begin{array}{c}\text { Latent } \\
\text { variables }\end{array}$ & Code & Observed variables & Sources \\
\hline \multirow{5}{*}{ 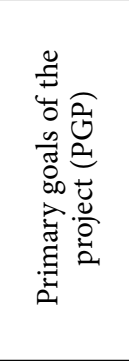 } & PGP1 & Completed within schedule & $\begin{array}{l}\text { (Flyvbjerg et al., 2003; Toor \& } \\
\text { Ogunlana, 2010) }\end{array}$ \\
\hline & PGP2 & Completed within budget & $\begin{array}{l}\text { (Flyvbjerg et al., 2003; Toor \& } \\
\text { Ogunlana, 2010) }\end{array}$ \\
\hline & PGP3 & Completed with high quality & $\begin{array}{l}\text { (Flyvbjerg et al., 2003; Toor \& } \\
\text { Ogunlana, 2010) }\end{array}$ \\
\hline & PGP4 & $\begin{array}{l}\text { Meeting the health and safety } \\
\text { requirements }\end{array}$ & (Xie et al., 2017; Hu et al., 2016) \\
\hline & PGP5 & Meeting the functional requirements & (Shenhar \& Holzmann, 2017) \\
\hline \multirow{3}{*}{ 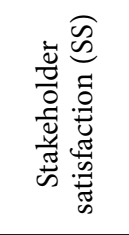 } & SS1 & $\begin{array}{l}\text { Governments are satisfied with the } \\
\text { project }\end{array}$ & $\begin{array}{l}\text { (Flyvbjerg, 2014; Crawford \& Helm, } \\
\text { 2009) }\end{array}$ \\
\hline & SS2 & $\begin{array}{l}\text { The public are satisfied with the } \\
\text { project }\end{array}$ & $\begin{array}{l}\text { (Xie et al., 2017; Hanna et al., 2014; } \\
\text { Di Maddaloni \& Davis, 2017) }\end{array}$ \\
\hline & SS3 & $\begin{array}{l}\text { The stakeholders (e.g., contractors) } \\
\text { are satisfied with the project }\end{array}$ & $\begin{array}{l}\text { (Toor \& Ogunlana, 2010; Pinto et al., } \\
\text { 2009; Hanna et al., 2014) }\end{array}$ \\
\hline \multirow{3}{*}{ 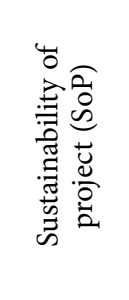 } & SoP1 & $\begin{array}{l}\text { Environment-friendly (e.g., the } \\
\text { project prevents or mitigates the } \\
\text { negative environmental impact on } \\
\text { local community) }\end{array}$ & $\begin{array}{l}\text { (Chen \& Manley, 2014; Xie et al., } \\
\text { 2017) }\end{array}$ \\
\hline & SoP2 & $\begin{array}{l}\text { Durability (e.g., the project will not } \\
\text { be eliminated too soon) }\end{array}$ & (Toor \& Ogunlana, 2010) \\
\hline & SoP3 & Social harmony and stability & $\begin{array}{l}\text { (Xie et al., 2017; Shenhar \& } \\
\text { Holzmann, 2017) }\end{array}$ \\
\hline
\end{tabular}

\subsection{Hypothesis development}

In order to check the possible impact of governmental governance imposed on megaproject performance, a hypothesized structural equation model was established, as shown in Figure 1. The development of the model adopted the approach recommended by (Wetzels et al., 2009), which makes measurement and hierarchical models as interpretable as possible. The model consists of nine measurement models and one structural model. Governmental governance in the hypothesis model is considered as six-dimensional and second-order variable composed of strategic planning, institutional design, regulatory oversight, public monitoring and scrutiny, construction of clean government, and systemic risk management. Megaproject performance is deemed as a three-dimensional and second-order variable composed primary goals of project, stakeholder satisfaction and sustainability of project. Based on previous stud- 


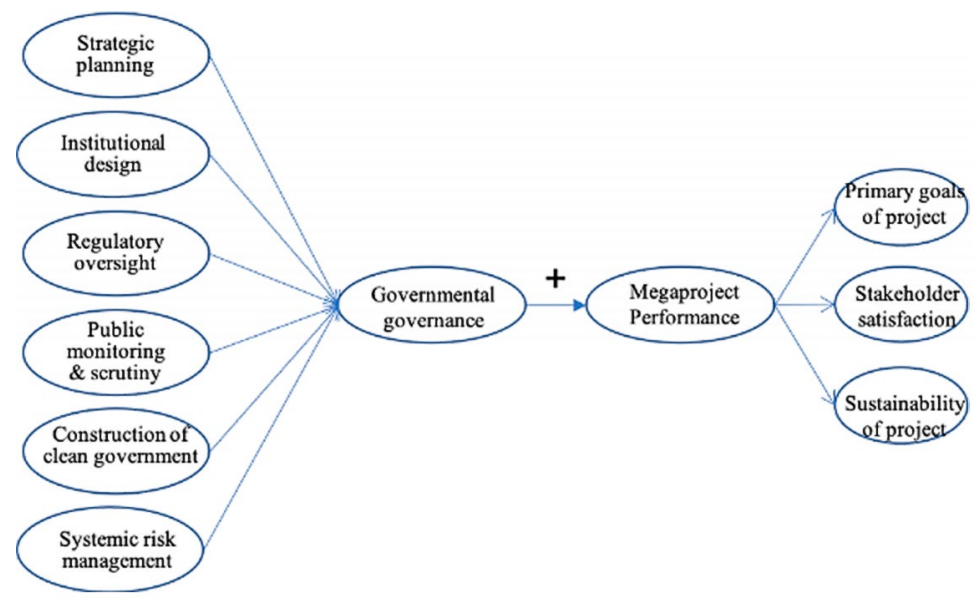

Figure 1. The hypothesized structural equation model of governmental governance and megaproject performance

ies mentioned above, the structural model measures the relationships between governmental governance and megaproject performance, hypothesizing that governmental governance can help improve the performance of megaprojects. The impacts of governmental governance imposed on megaproject performance can be revealed by testing the hypothesized model.

\section{Research methods and data presentation}

Various research methods, such as structured interview, questionnaire, and post-survey interviews, were adopted in this study. By using multiple methods, consistent relationships among variables can be detected, which brings greater confidence in tests of the hypotheses(Abowitz $\&$ Toole, 2010). It was expected that multi-dimensional results could triangulate and enhance the study's validity and reliability.

In the research of construction management, structured interviews with experienced industry experts are widely used to define the central themes of some specific research subject (Hwang et al., 2018b; Shan et al., 2017; Zhao \& Singhaputtangkul, 2016). Thus, this study used structured interview as instrument to verify the theoretical framework of governmental governance and megaproject performance that were established from literature review. Because the framework is based on international research, before adopting them to develop the questionnaire, all variables should be verified through interviews. Interviews were conducted between May and July 2017 with 35 experts who are mainly from industry and academy. The interviewees were identified from the network of the research institution that the authors affiliate. Additionally, to maintain a sound understanding of the research study, only experts who hold senior positions within their organizations were invited. The profile of the interviewees is presented in Table 3 and the diversity of the backgrounds among the experts was expected to increase the quality and reliability of the results of the interviews. 
Table 3. Interviewee profile

\begin{tabular}{|c|c|c|c|}
\hline Profile & Category & Number & $\%$ \\
\hline \multirow{6}{*}{ Institution } & Government & 5 & 14.29 \\
\hline & Client & 12 & 34.29 \\
\hline & Academic & 2 & 5.71 \\
\hline & Consultant & 7 & 20.00 \\
\hline & Designer & 3 & 8.57 \\
\hline & Contractor & 6 & 17.14 \\
\hline \multirow{5}{*}{ Position } & Division chief & 5 & 14.29 \\
\hline & Project manager & 9 & 25.71 \\
\hline & Deputy director & 2 & 5.71 \\
\hline & Senior engineer & 7 & 20.00 \\
\hline & Department manager & 12 & 34.29 \\
\hline \multirow{5}{*}{ Years of experience in megaprojects } & Less than 5 years & 1 & 2.86 \\
\hline & $5-10$ & 14 & 40.00 \\
\hline & $11-20$ & 15 & 42.86 \\
\hline & $21-30$ & 3 & 8.57 \\
\hline & More than 30 years & 2 & 5.71 \\
\hline \multirow{4}{*}{ The types of the megaprojects conducted } & Transportation & 13 & 37.14 \\
\hline & Energy & 3 & 8.57 \\
\hline & Water conservancy project & 8 & 22.86 \\
\hline & Unban infrastructure & 11 & 31.43 \\
\hline \multirow{4}{*}{ Working place } & North-eastern China & 3 & 8.57 \\
\hline & Eastern China & 15 & 42.86 \\
\hline & Central China & 4 & 11.43 \\
\hline & Western China & 13 & 37.14 \\
\hline
\end{tabular}

Table 4. Profile of questionnaire respondents

\begin{tabular}{|c|c|c|}
\hline Description & Number & Percentage \\
\hline \multicolumn{3}{|c|}{ Year of experience in megaprojects } \\
\hline $1-5$ years & 53 & $22.20 \%$ \\
\hline $6-10$ years & 98 & $41.00 \%$ \\
\hline $11-20$ years & 65 & $27.20 \%$ \\
\hline $21-30$ years & 23 & $9.60 \%$ \\
\hline \multicolumn{3}{|c|}{ Institutions } \\
\hline Government & 7 & $2.90 \%$ \\
\hline Client & 83 & $34.70 \%$ \\
\hline Designer & 20 & $8.40 \%$ \\
\hline Contractor & 58 & $24.30 \%$ \\
\hline
\end{tabular}


End of Table 4

\begin{tabular}{|l|c|c|}
\hline \multicolumn{1}{|c|}{ Description } & Number & Percentage \\
\hline Consultant & 63 & $26.40 \%$ \\
\hline Research Institution & 8 & $3.30 \%$ \\
\hline \multicolumn{2}{|c|}{ Positions } \\
\hline Top managerial level (e.g., director, general manager) & 46 & $19.20 \%$ \\
\hline Middle managerial level (e.g., project manager) & 115 & $48.10 \%$ \\
\hline Professional (e.g., engineer, quantity surveyor) & 78 & $32.60 \%$ \\
\hline
\end{tabular}

Questionnaire has been long established in construction engineering and management research to present detailed analysis of the views of professionals on some particular topic in construction engineering and management research (Chen et al., 2019; Hwang et al., 2018a). Thus, this study adopted questionnaire to gather the perceptions of the professionals regarding the observed variables in the frameworks of governmental governance and megaproject performance. Based on the results obtained from the structured interviews, a questionnaire was formulated, in which the respondents were asked to indicate their endorsement on the observed variables of governmental governance and megaproject performance. The population of the survey targets governmental officials, clients, contractors, consultants, and academics who have experiences in conducting megaprojects in China. Following the recommendation of Shan et al. (2017), the questionnaire used a nonprobability sampling approach which is expert sampling. Under such sampling approach, some qualified experts are selected and then invited to fill in the questionnaire. This is because there are too many officials, professionals, and academics qualified for the questionnaire and it would be extremely difficult to survey them all. Specifically, 1000 experts from 1000 megaprojects in ten major cities of China, namely Beijing, Shanghai, Chongqing, Guangzhou, Shenzhen, Chengdu, Xi'an, Nanjing, Zhengzhou, and Changchun were contacted for data collection (100 projects for each city). The contacts of these experts were obtained from the Megaproject Offices of these cities, with the help of the networks of the research team's institution. Electronic copies of the questionnaire were sent to experts via emails and 297 replies were returned. After a careful visual examination, 58 replies were excluded due to low level of completeness. Lastly, 239 valid replies were obtained. The profile of the respondents and the information of the projects those respondents have conducted are presented in Tables 4 and 5, respectively. From Table 4 we can see that two-thirds of the respondents are holding management positions in their organizations and nearly 40 percent of them have over ten years of experiences in working on megaprojects. This implies that the respondent panel is familiar with the governance topic and also experienced enough for the questionnaire.

Partial least squares-structural equation modeling (PLS-SEM) was used to test the hypothesized structural equation model, using the data collected by the questionnaire. This approach was adopted due to the following advantages: (1) being able to address complex problems with a relatively small sample size, and (2) having no particular requirement for data distribution (Shan et al., 2017; Zhao et al., 2018). Following the recommendation of Hair et al. (2011), three indicators were used to check the test results of measurement models, which 
Table 5. Profile of megaprojects participated by questionnaire respondents

\begin{tabular}{|c|c|c|}
\hline Description & Number & Percentage \\
\hline \multicolumn{3}{|c|}{ Project type } \\
\hline Transportation & 67 & $28.0 \%$ \\
\hline Energy & 18 & $7.5 \%$ \\
\hline Water safety & 37 & $15.5 \%$ \\
\hline Urban infrastructure & 112 & $46.9 \%$ \\
\hline Ocean engineering & 5 & $2.1 \%$ \\
\hline \multicolumn{3}{|c|}{ Project Cost } \\
\hline Less than CNY 1 billion (approx. USD 0.15 billion) & 42 & $17.6 \%$ \\
\hline CNY 1-2 billion (approx. USD $0.15-0.3$ billion) & 82 & $34.3 \%$ \\
\hline CNY 2-3 billion (approx. USD $0.3-0.45$ billion) & 61 & $25.5 \%$ \\
\hline CNY 3-4 billion (approx. USD $0.45-0.6$ billion) & 21 & $8.8 \%$ \\
\hline Over CNY 4 billion (approx. USD 0.6 billion) & 33 & $13.8 \%$ \\
\hline \multicolumn{3}{|c|}{ Project location } \\
\hline Northeastern China & 7 & $2.9 \%$ \\
\hline Eastern China & 142 & $59.4 \%$ \\
\hline Central China & 42 & $17.6 \%$ \\
\hline Western China & 48 & $20.1 \%$ \\
\hline
\end{tabular}

are composite reliability, loadings of observed variables, and average variance extracted; and critical t-value was used to check the test result of structural model (Hair et al., 2011). The test results of PLS-SEM will reveal whether the hypothesis of this research study is supported and which latent variable is more critical to megaproject performance.

The final stage of the study comprised post-survey interviews with five experts who worked in the same megaproject. Among those interviewees, two were from a developer whereas the other three were from government agency, consultancy, and main contractor, respectively. Results obtained from the questionnaire were presented to the experts to test the validity. Furthermore, the five experts were asked to provide in-depth explanations for the results wherever necessary. Each interview lasted from thirty minutes to one hour. The outputs of the post-survey interviews can triangulate the findings revealed by structural equation modelling analysis, making the findings of this study more convincing.

\section{Results and discussions}

\subsection{Results of structured interviews}

During the interviews, interviewees were requested to assess the applicability of the observed variables identified by the literature review, using a five-point Likert rating scale (i.e., 1 = very inapplicable, 2 = inapplicable, $3=$ neutral, $4=$ applicable, $5=$ highly applicable) . Furthermore, interviewees were encouraged to supplement new variables based on their practical experiences. To identify the valid observed variables of governmental governance 
and megaproject performance, mean scores of all observed variables were calculated and then applied to a cut off criterion of 3.0, following the recommendation of Hwang et al. (2018b). According to the results shown in Table 6, ID25 "incentives for high-performance co-ordination from higher levels of government" was removed as it received a mean of 2.943. Additionally, two new observed variables, namely "proper solutions for resettlement" and "labour emulation", were added by the interviewee panel to measure governmental governance, under the latent variables of "strategic planning" and "construction of clean government", respectively. Resettlement is involuntary to most of the residents affected by megaprojects (Jackson \& Sleigh, 2000), and civil disorder might occur if the resettlement is poorly planned and managed (Shi et al. 2015). Labour emulation is designed by the construction authorities of China to develop friendly competition between organizations working on a same project, aiming to encourage the less advanced units to catch up with the more advanced one (Tung, 1981), and ultimately ensuring the whole success of the entire project. After the new observed variables were added, all the interviewees were contacted again to evaluate the supplement. While a minority of the interviewees mentioned that those two observed variables were not important, the majority agreed that they should be included into the observed variables assessing governmental governance. Table 6 presents all the observed variables of governmental governance and megaproject performance.

Table 6. Observed variables of governmental governance and megaproject performance

\begin{tabular}{|c|c|c|c|}
\hline $\begin{array}{c}\text { Latent } \\
\text { variables }\end{array}$ & Code & Observed variables & Mean \\
\hline \multirow{5}{*}{$\begin{array}{l}\text { Strategic } \\
\text { Planning (SP) }\end{array}$} & SP11 & Presence of a feasible strategic plan & 3.857 \\
\hline & SP12 & Budget al.ocation to projects in plan & 4.114 \\
\hline & SP13 & Dedicated procedure for governing the project & 3.829 \\
\hline & SP14 & Formal top governance committees or platforms to make decision & 4.000 \\
\hline & SP15 & Proper solutions for resettlement in the front-end phase & 4.029 \\
\hline \multirow{5}{*}{$\begin{array}{l}\text { Institutional } \\
\text { Design (ID) }\end{array}$} & ID21 & $\begin{array}{l}\text { A clear set of documents of responsibilities for all levels of } \\
\text { government involved }\end{array}$ & 3.886 \\
\hline & ID22 & Formal set of criteria to determine how to deliver the project & 3.971 \\
\hline & ID23 & $\begin{array}{l}\text { Formal co-ordination mechanisms (such as meetings) are } \\
\text { frequently used and produce clear outputs/outcomes }\end{array}$ & 4.057 \\
\hline & ID24 & $\begin{array}{l}\text { Informal co-ordination mechanisms (such as private } \\
\text { communications) are frequently used between government and } \\
\text { stakeholders }\end{array}$ & 3.686 \\
\hline & ID25 $5^{\mathrm{b}}$ & $\begin{array}{l}\text { Incentives for high-performance co-ordination from higher levels } \\
\text { of government }\end{array}$ & 2.943 \\
\hline \multirow{5}{*}{$\begin{array}{l}\text { Regulatory } \\
\text { Oversight } \\
\text { (RO) }\end{array}$} & RO31 & Powerful regulatory mechanism for the project & 3.857 \\
\hline & RO32 & Multi-level regulatory systems for the project & 3.971 \\
\hline & RO33 & Independent regulatory authority for the project & 3.686 \\
\hline & RO34 & Regulatory authority governs the project within legal authority & 3.571 \\
\hline & $\mathrm{RO} 35$ & $\begin{array}{l}\text { Confidence of stakeholders enhanced by the regulatory } \\
\text { mechanisms }\end{array}$ & 3.457 \\
\hline
\end{tabular}


End of Table 6

\begin{tabular}{|c|c|c|c|}
\hline $\begin{array}{c}\text { Latent } \\
\text { variables }\end{array}$ & Code & Observed variables & Mean \\
\hline \multirow{7}{*}{$\begin{array}{l}\text { Public } \\
\text { Monitoring } \\
\text { and Scrutiny } \\
\text { (PMS) }\end{array}$} & PMS41 & Transparent plans for the project & 3.486 \\
\hline & PMS42 & The public can question and give advice in the planning phase & 3.286 \\
\hline & PMS43 & The public can participate in the project in the construction phase & 3.200 \\
\hline & PMS44 & Disclosure of data in an open format on a dedicated website & 3.657 \\
\hline & PMS45 & $\begin{array}{l}\text { Dedicated procedure for balancing the interests between public } \\
\text { and private parties }\end{array}$ & 3.514 \\
\hline & PMS46 & Presence of a sound audit system & 4.029 \\
\hline & PMS47 & Disclosure of audit results & 3.343 \\
\hline \multirow{5}{*}{$\begin{array}{l}\text { Construction } \\
\text { of clean } \\
\text { government } \\
\text { (CCG) }\end{array}$} & CCG51 & Conflict of interest policies for government officials & 3.457 \\
\hline & CCG52 & Internal system to monitor and identify irregularities & 3.771 \\
\hline & CCG53 & Measures in place to identify the integrity of all participants & 3.829 \\
\hline & CCG54 & Mechanisms to report illegal behaviors related to megaprojects & 3.657 \\
\hline & CCG55 & labor emulations & 4.029 \\
\hline \multirow{5}{*}{$\begin{array}{l}\text { Systemic risk } \\
\text { management } \\
(\mathrm{SRM})\end{array}$} & SRM61 & Ability to determine the disaster prioritization & 3.943 \\
\hline & SRM62 & $\begin{array}{l}\text { The presence of government agencies answerable for post-disaster } \\
\text { reconstruction }\end{array}$ & 4.057 \\
\hline & SRM63 & The presence of a disaster risk assessment plan & 3.714 \\
\hline & SRM64 & The presence of emergency rescue system & 4.086 \\
\hline & SRM65 & Mechanisms in place to learn from past events & 3.600 \\
\hline \multirow{5}{*}{$\begin{array}{l}\text { Primary goals } \\
\text { of the project } \\
\text { (PGP) }\end{array}$} & PGP1 & Completed within schedule & 4.200 \\
\hline & PGP2 & Completed within budget & 3.971 \\
\hline & PGP3 & Completed with high quality & 4.143 \\
\hline & PGP4 & Meeting the health and safety requirements & 3.971 \\
\hline & PGP5 & Meeting the functional requirements & 3.829 \\
\hline \multirow{3}{*}{$\begin{array}{l}\text { Stakeholder } \\
\text { satisfaction } \\
\text { (SS) }\end{array}$} & SS1 & Governments are satisfied with the project & 3.800 \\
\hline & SS2 & The public are satisfied with the project & 4.000 \\
\hline & SS3 & The stakeholders (e.g., contractors) are satisfied with the project & 3.714 \\
\hline \multirow{3}{*}{$\begin{array}{l}\text { Sustainability } \\
\text { of project } \\
\text { (SoP) }\end{array}$} & SoP1 & $\begin{array}{l}\text { Environment-friendly (e.g., the project prevents or mitigates the } \\
\text { negative environmental impact on local community) }\end{array}$ & 4.057 \\
\hline & SoP2 & Durability (e.g., the project will not be eliminated too soon) & 3.857 \\
\hline & SoP3 & Social harmony and stability & 3.971 \\
\hline
\end{tabular}

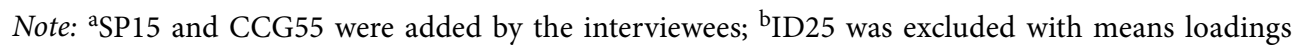
lower than 3.0. 


\subsection{Test results of the hypothesized structural equation model}

\subsubsection{Evaluation of measurement models}

Data was inserted into Smart PLS 2.0M3 to test the hypothesized model. The evaluation results of the measurement models are presented in Tables 7-9. It can be seen from Table 7 that the loadings of all observed variables are higher than 0.6 , suggesting a satisfactory level of indicator reliability; all composite reliability values are larger than 0.70 , suggesting the acceptable internal reliability of observed variables with their corresponding latent variables; and the values of average variance extracted are greater than 0.5 , showing a satisfactory level of convergent validity for all the latent variables (Hair et al., 2011; Le et al., 2014; Liu et al., 2017; Zhao \& Singhaputtangkul, 2016).

Table 8 shows that square root of each latent variable's average variance extracted is greater than its highest correlation with any other latent variable. Table 9 indicates that each observed variable's outer loading on the associated latent variable is greater than all of its cross loadings. These results suggest that the latent variables in the hypothesized model have a high discriminant validity (Hair et al., 2011).

Table 7. Measurement model evaluation

\begin{tabular}{|c|c|c|c|c|c|}
\hline Latent variables & Code & Loading & $\mathrm{t}$-value & AVE & $\mathrm{CR}$ \\
\hline \multirow{5}{*}{ SP } & SP11 & 0.864 & 50.364 & \multirow{5}{*}{0.688} & \multirow{5}{*}{0.917} \\
\hline & SP12 & 0.838 & 32.508 & & \\
\hline & SP13 & 0.857 & 40.134 & & \\
\hline & SP14 & 0.814 & 27.826 & & \\
\hline & SP15 & 0.772 & 18.972 & & \\
\hline \multirow{4}{*}{ ID } & ID21 & 0.854 & 52.568 & \multirow{4}{*}{0.599} & \multirow{4}{*}{0.855} \\
\hline & ID22 & 0.778 & 18.126 & & \\
\hline & ID23 & 0.831 & 33.044 & & \\
\hline & ID24 & 0.611 & 8.726 & & \\
\hline \multirow{5}{*}{ RO } & RO31 & 0.870 & 33.151 & \multirow{5}{*}{0.748} & \multirow{5}{*}{0.937} \\
\hline & RO32 & 0.865 & 31.291 & & \\
\hline & RO33 & 0.857 & 25.523 & & \\
\hline & RO34 & 0.867 & 47.936 & & \\
\hline & RO35 & 0.865 & 44.963 & & \\
\hline \multirow{7}{*}{ PMS } & PMS41 & 0.784 & 28.024 & \multirow{7}{*}{0.597} & \multirow{7}{*}{0.912} \\
\hline & PMS42 & 0.724 & 38.625 & & \\
\hline & PMS43 & 0.761 & 24.505 & & \\
\hline & PMS44 & 0.773 & 23.361 & & \\
\hline & PMS45 & 0.767 & 24.547 & & \\
\hline & PMS46 & 0.754 & 26.222 & & \\
\hline & PMS47 & 0.741 & 22.623 & & \\
\hline
\end{tabular}


End of Table 7

\begin{tabular}{|c|c|c|c|c|c|}
\hline Latent variables & Code & Loading & $\mathrm{t}$-value & AVE & CR \\
\hline \multirow{5}{*}{ CCG } & CCG51 & 0.780 & 20.182 & \multirow{5}{*}{0.647} & \multirow{5}{*}{0.901} \\
\hline & CCG52 & 0.827 & 26.886 & & \\
\hline & CCG53 & 0.852 & 35.07 & & \\
\hline & CCG54 & 0.849 & 41.61 & & \\
\hline & CCG55 & 0.704 & 19.243 & & \\
\hline \multirow{5}{*}{ SRM } & SRM61 & 0.884 & 57.224 & \multirow{5}{*}{0.786} & \multirow{5}{*}{0.948} \\
\hline & SRM62 & 0.909 & 66.775 & & \\
\hline & SRM63 & 0.883 & 60.581 & & \\
\hline & SRM64 & 0.889 & 47.768 & & \\
\hline & SRM65 & 0.857 & 41.96 & & \\
\hline \multirow{5}{*}{ PGP } & PGP1 & 0.747 & 17.564 & \multirow{5}{*}{0.684} & \multirow{5}{*}{0.915} \\
\hline & PGP2 & 0.796 & 28.864 & & \\
\hline & PGP3 & 0.887 & 54.552 & & \\
\hline & PGP4 & 0.857 & 32.525 & & \\
\hline & PGP5 & 0.840 & 38.109 & & \\
\hline \multirow{3}{*}{ SS } & SS1 & 0.784 & 22.601 & \multirow{3}{*}{0.771} & \multirow{3}{*}{0.91} \\
\hline & SS2 & 0.904 & 105.003 & & \\
\hline & SS3 & 0.910 & 78.422 & & \\
\hline \multirow{3}{*}{ SoP } & SoP1 & 0.818 & 29.517 & \multirow{3}{*}{0.703} & \multirow{3}{*}{0.876} \\
\hline & SoP2 & 0.813 & 28.436 & & \\
\hline & SoP3 & 0.883 & 47.571 & & \\
\hline
\end{tabular}

Table 8. Correlation matrix and square root of average variance extracted of latent variables

\begin{tabular}{|c|c|c|c|c|c|c|c|c|c|}
\hline & SP & ID & RO & PMS & CCG & SRM & PGP & SS & SoP \\
\hline SP & 0.830 & & & & & & & & \\
\hline ID & 0.814 & 0.774 & & & & & & & \\
\hline RO & 0.780 & 0.769 & 0.865 & & & & & & \\
\hline PMS & 0.700 & 0.724 & 0.765 & 0.773 & & & & & \\
\hline CCG & 0.654 & 0.713 & 0.725 & 0.766 & 0.804 & & & & \\
\hline SRM & 0.579 & 0.644 & 0.686 & 0.664 & 0.765 & 0.887 & & & \\
\hline PGP & 0.552 & 0.587 & 0.539 & 0.627 & 0.639 & 0.647 & 0.827 & & \\
\hline SS & 0.456 & 0.504 & 0.461 & 0.601 & 0.619 & 0.593 & 0.769 & 0.878 & \\
\hline SoP & 0.445 & 0.518 & 0.479 & 0.560 & 0.598 & 0.571 & 0.736 & 0.747 & 0.838 \\
\hline
\end{tabular}


Table 9. Cross loadings for observed variables under different latent variables

\begin{tabular}{|c|c|c|c|c|c|c|c|c|c|}
\hline & SP & ID & RO & PMS & CCG & SRM & PGP & SS & SoP \\
\hline SP11 & 0.864 & 0.701 & 0.667 & 0.655 & 0.594 & 0.537 & 0.544 & 0.454 & 0.471 \\
\hline SP12 & 0.838 & 0.661 & 0.645 & 0.558 & 0.530 & 0.449 & 0.429 & 0.342 & 0.326 \\
\hline SP13 & 0.857 & 0.697 & 0.658 & 0.583 & 0.574 & 0.525 & 0.470 & 0.404 & 0.357 \\
\hline SP14 & 0.814 & 0.647 & 0.631 & 0.520 & 0.515 & 0.451 & 0.386 & 0.305 & 0.293 \\
\hline SP15 & 0.772 & 0.670 & 0.634 & 0.581 & 0.491 & 0.430 & 0.451 & 0.377 & 0.388 \\
\hline ID21 & 0.746 & 0.854 & 0.709 & 0.672 & 0.638 & 0.560 & 0.550 & 0.467 & 0.482 \\
\hline ID22 & 0.697 & 0.778 & 0.590 & 0.559 & 0.489 & 0.423 & 0.403 & 0.330 & 0.306 \\
\hline ID23 & 0.642 & 0.831 & 0.678 & 0.570 & 0.633 & 0.588 & 0.514 & 0.434 & 0.464 \\
\hline ID24 & 0.386 & 0.611 & 0.461 & 0.411 & 0.419 & 0.400 & 0.312 & 0.308 & 0.330 \\
\hline RO31 & 0.678 & 0.734 & 0.870 & 0.634 & 0.619 & 0.576 & 0.473 & 0.346 & 0.420 \\
\hline RO32 & 0.609 & 0.690 & 0.865 & 0.620 & 0.575 & 0.531 & 0.462 & 0.372 & 0.435 \\
\hline RO33 & 0.681 & 0.627 & 0.857 & 0.622 & 0.576 & 0.546 & 0.396 & 0.326 & 0.343 \\
\hline RO34 & 0.685 & 0.666 & 0.867 & 0.679 & 0.679 & 0.647 & 0.450 & 0.464 & 0.406 \\
\hline RO35 & 0.713 & 0.728 & 0.865 & 0.743 & 0.675 & 0.654 & 0.539 & 0.475 & 0.462 \\
\hline PMS41 & 0.700 & 0.659 & 0.677 & 0.784 & 0.579 & 0.562 & 0.517 & 0.468 & 0.444 \\
\hline PMS42 & 0.543 & 0.580 & 0.650 & 0.824 & 0.607 & 0.603 & 0.487 & 0.451 & 0.424 \\
\hline PMS43 & 0.388 & 0.461 & 0.503 & 0.761 & 0.516 & 0.404 & 0.396 & 0.409 & 0.340 \\
\hline PMS44 & 0.515 & 0.544 & 0.556 & 0.773 & 0.583 & 0.496 & 0.495 & 0.475 & 0.438 \\
\hline PMS45 & 0.478 & 0.569 & 0.607 & 0.767 & 0.566 & 0.477 & 0.483 & 0.434 & 0.408 \\
\hline PMS46 & 0.648 & 0.604 & 0.615 & 0.755 & 0.643 & 0.503 & 0.529 & 0.504 & 0.540 \\
\hline PMS47 & 0.468 & 0.470 & 0.500 & 0.741 & 0.640 & 0.524 & 0.470 & 0.503 & 0.414 \\
\hline CCG51 & 0.482 & 0.552 & 0.560 & 0.668 & 0.780 & 0.506 & 0.467 & 0.419 & 0.442 \\
\hline CCG52 & 0.553 & 0.611 & 0.623 & 0.649 & 0.827 & 0.634 & 0.541 & 0.528 & 0.490 \\
\hline CCG53 & 0.503 & 0.575 & 0.616 & 0.650 & 0.852 & 0.646 & 0.528 & 0.572 & 0.511 \\
\hline CCG54 & 0.599 & 0.631 & 0.618 & 0.626 & 0.849 & 0.648 & 0.547 & 0.520 & 0.523 \\
\hline CG55 & 0.485 & 0.490 & 0.487 & 0.475 & 0.704 & 0.643 & 0.485 & 0.441 & 0.431 \\
\hline SRM61 & 0.492 & 0.542 & 0.574 & 0.598 & 0.712 & 0.884 & 0.591 & 0.528 & 0.521 \\
\hline SRM62 & 0.461 & 0.560 & 0.602 & 0.593 & 0.673 & 0.909 & 0.615 & 0.539 & 0.530 \\
\hline SRM63 & 0.557 & 0.603 & 0.648 & 0.595 & 0.659 & 0.893 & 0.589 & 0.540 & 0.565 \\
\hline SRM64 & 0.477 & 0.552 & 0.602 & 0.558 & 0.674 & 0.889 & 0.510 & 0.472 & 0.439 \\
\hline SRM65 & 0.575 & 0.595 & 0.613 & 0.600 & 0.673 & $\mathbf{0 . 8 5 7}$ & 0.559 & 0.546 & 0.472 \\
\hline PGP1 & 0.492 & 0.483 & 0.435 & 0.509 & 0.511 & 0.524 & 0.747 & 0.620 & 0.457 \\
\hline PGP2 & 0.410 & 0.416 & 0.404 & 0.510 & 0.508 & 0.451 & 0.796 & 0.600 & 0.577 \\
\hline PGP3 & 0.456 & 0.472 & 0.436 & 0.495 & 0.552 & 0.570 & $\mathbf{0 . 8 8 7}$ & 0.651 & 0.680 \\
\hline PGP4 & 0.496 & 0.572 & 0.507 & 0.549 & 0.570 & 0.589 & 0.857 & 0.616 & 0.653 \\
\hline PGP5 & 0.434 & 0.483 & 0.447 & 0.536 & 0.501 & 0.536 & 0.840 & 0.690 & 0.656 \\
\hline SS1 & 0.331 & 0.375 & 0.336 & 0.435 & 0.413 & 0.383 & 0.547 & 0.784 & 0.466 \\
\hline SS2 & 0.459 & 0.512 & 0.473 & 0.608 & 0.629 & 0.606 & 0.728 & 0.934 & 0.709 \\
\hline SS3 & 0.401 & 0.432 & 0.398 & 0.526 & 0.568 & 0.549 & 0.731 & 0.910 & 0.758 \\
\hline SoP1 & 0.414 & 0.470 & 0.452 & 0.482 & 0.526 & 0.567 & 0.661 & 0.642 & 0.818 \\
\hline SoP2 & 0.306 & 0.362 & 0.362 & 0.421 & 0.425 & 0.392 & 0.552 & 0.611 & 0.813 \\
\hline SoP3 & 0.393 & 0.464 & 0.388 & 0.502 & 0.546 & 0.470 & 0.634 & 0.625 & 0.883 \\
\hline
\end{tabular}




\subsubsection{Evaluation of structural model}

Table 10 shows the results of the path coefficients and the corresponding t-values of the structural model. It can be seen from Table 10 that the $t$-values of all the paths are greater than 2.58. This indicates that all these paths are statistically significant at the level of 0.01 (Hair et al., 2011). Particularly, the path coefficient between "governmental governance" and "megaproject performance" is significant $(\mathrm{t}$-value $=15.946, \mathrm{p}<0.01)$ and has a high path coefficient of 0.708 . This proves that the hypothesis of this study, namely "governmental governance" can help improve the performance of megaprojects, is supported. The results obtained from the PLS-SEM analysis are shown in Figure 2.

Table 10. Evaluation of structural model

\begin{tabular}{|c|c|c|c|}
\hline Paths & Path coefficient & T-value & CR \\
\hline SP $->$ GG & 0.176 & 21.281 & 0.970 \\
\hline ID $->$ GG & 0.130 & 23.067 & \\
\hline RO -> GG & 0.200 & 25.075 & \\
\hline PMS -> GG & 0.236 & 26.159 & \\
\hline CCG -> GG & 0.185 & 22.685 & \\
\hline SRM -> GG & 0.215 & 21.237 & \\
\hline MP -> PGP & 0.942 & 106.755 & \\
\hline MP -> SS & 0.907 & 69.655 & \\
\hline MP -> SoP & 0.883 & 56.766 & \\
\hline
\end{tabular}

\subsection{Critical components of governmental governance: from the view of megaproject performance}

Based on the results of path coefficient of different latent variables of governmental governance, "public monitoring and scrutiny" was found to be the most critical component of governmental governance in sense of improving megaproject performance, followed by "systemic risk management", "regulatory oversight", "construction of clean government", "strategic planning" and "institutional design".

"Public monitoring and scrutiny" (PMS) was found to be the most critical component of governmental governance with a path coefficient of 0.236 . In the past few years, public participation has been increasingly employed in the megaproject sector of China. Various approaches that can help increase public participation, such as consultative meetings, public hearings, surveys and workshops, have been widely adopted ( $\mathrm{Ng}$ et al. 2012; Xie et al. 2017). Moreover, some evaluation systems of public participation widely used in democratic contexts also confirmed the improvement of public participation in China. For example, Arnstein (1969) proposed an eight-level scale that can be used to assess levels of citizen participation. According to Arnstein's scale, the degree of participation climbs up from nonparticipation to citizen power. The sixth level "partnership", at which power is "redistributed through negotiation between citizens and powerholders", fits for the majority of public participation in the megaproject sector of China. This is a favorable score and is mainly because many megaprojects in the transportation sector of China have adopted the approach of Public-Private Partnership which is a typical type of "partnership" (Xie et al. 2017; Zhang et al., 2018). 


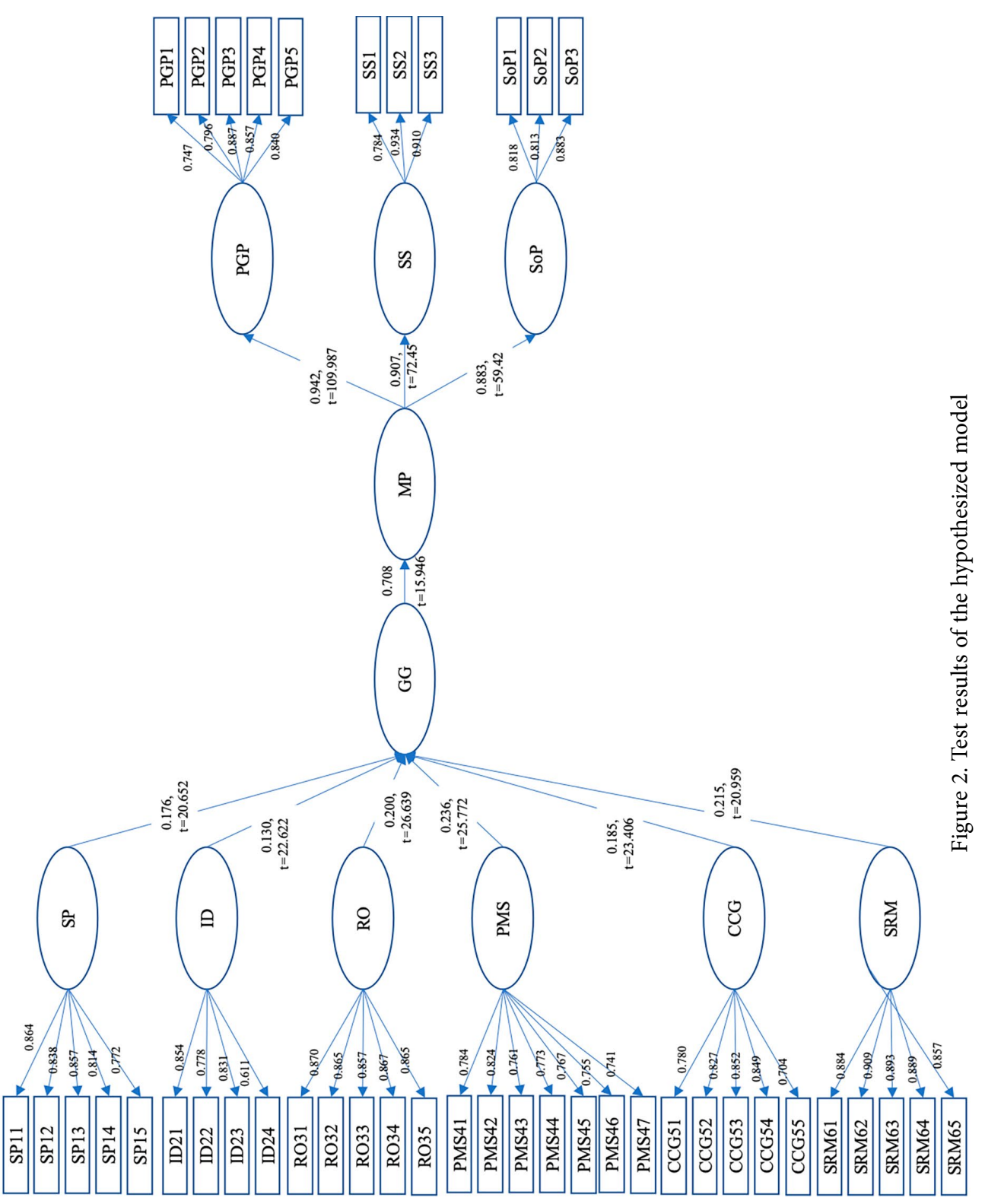


As for the specific variables under PMS, public participation in the front-end phase (PMS42) had the highest factor loading (0.824) on PMS. Experience from developed countries is that the public should be involved in projects as early as possible (Flyvbjerg et al., 2003). The absence of public in front-end phase may be more challenging to megaprojects as obstructing construction process may cause social disorder and conflict (Liu et al., 2016; Shi et al., 2015), thus increasing the chance of project failure (Li et al., 2016; Ng et al., 2012). "Transparent plans for the project" (PMS41) had the second highest factor loading (0.784), and the disclosure of data in an open format on a dedicated website (PMS44) received the third highest loading (0.773). That is largely on account of the need for transparency across government's operations to enable the public to hold government bodies to account. Flyvbjerg et al. (2003) proposes that transparency is the main instruments of enforcing accountability in megaproject, which means the public shoulde get access to governmental information about megaprojects. The requirement of transparency is also based on the fact that megaprojects may affect human lives and livelihoods, and the public deserve being informed early, even to be pro-actively involved in the decision-making process.

"Systemic risk management" (SRM) is the second most critical component of governmental governance with a path coefficient of 0.215 . Megaprojects might pose various challenges to the local community and government (Aarseth et al., 2017), and systemic risk management is strongly needed for addressing those challenges. The highest loading is the presence of designed authorities (SRM62), followed by presence of a disaster risk assessment plan (SRM63). The results match those observed in earlier studies (Bozza et al., 2017; Vahanvati \& Mulligan, 2017). Setting strategic and tactical goals of sustainability is one of the main strategies advocated by the government agency (Aarseth et al., 2017). Lower factor loadings are "presence of emergency rescue system" (0.889) and "ability to determine the disaster prioritization" (0.884), which represent projects' response and their capability to deal more successfully with occurrence of risk, accident or disaster (Bozza et al., 2017). Although learning mechanism got the lowest factor loading (0.857), it is essential for improving response speed as emergency arise.

"Regulatory oversight" (RO) is the third most critical component of governmental governance with a path coefficient of 0.200 . Under this latent variable, powerful regulatory mechanism (RO31) and legitimate regulatory authority ( $\mathrm{RO} 34)$ received the highest factor loadings ( 0.870 and 0.867$)$. The government must retain regulatory oversight as an essential function, looking for approaches to improve quality of megaprojects and establish clear regulatory policy objectives. Oversight mechanism would be much more effective if governments adopt powerful and legitimate mechanism (Stoney \& Krawchenko, 2012). There are local authorities with regulatory powers and legal departments of legislative branches in charge of producing regulations and supervising implementation of megaprojects in China. For instance, in Shanghai, an authority named "megaproject office" is established within Shanghai Housing and Urban-Rural Development Management Committee, aiming at putting efforts to enhance regulatory policy on local megaprojects. Furthermore, there are "megaproject offices" in every district under municipal government's jurisdiction. Those authorities constitute a multi-level regulatory system (RO32), which is in the model, received the third highest rank as well as enhanced stakeholder confidence (RO35). The former reflects multi-level 
governance trends in megaprojects (Biesenthal \& Wilden, 2014), and the latter leads to the goal of oversight. The multi-layered governance mechanism can improve budgets' allocation while controlling the contingency drawdown (Flyvbjerg et al., 2016).

"Construction of clean government" (CCG) received a path coefficient of 0.185 and was the fourth most critical component of governmental governance. Opportunities for corruption, which is an international issue in both developing and developed countries (Besfamille, 2004), should be mitigated at each stage of the development of megaprojects. The highest factor loading (0.852) on this latent variable is measures to control the integrity of firms (CCG53). This accords with earlier observations in the interview with one expert, "there must be a pre-inspection system to inspect their previous projects. For example, if the onsite personnel were not as same as they proposed in bidding, we have reasons to believe that they may do so in our project. Hence, the company should be excluded." The result is also in line with those of previous studies showing measurement and causes of corruption in China's construction projects (Shan et al., 2015b; Zhang et al., 2017). After CCG53, mechanisms to report wrongdoings (CCG54) and system of internal controls (CCG52) received the second and third factor loadings (0.849 and 0.827$)$ on CCG. Lacking report mechanism or internal control both lead to be flawed regulation system, which causes corruption in public sectors (Le et al., 2014). CCG53 could be viewed as an external control process when compared to CCG52. As core actors, government officials are the target of companies who want to participate in megaprojects. Additionally, labour emulation, as part of the CPC Party conduct, has been adopted in Chinese construction projects over the years. Multi-level labour emulations are provided during the megaproject development, such as nation-level demonstration labour emulation areas in Three Gorges Project, Shanghai 2010 EXPO, and Hong Kong-Zhuhai-Macao Bridge, as well as some local emulations in major projects.

"Strategic planning" (SP) was the fifth most critical component of governmental governance, with a path coefficient of 0.176 . Although the economic transition in China has generated more opportunities in construction industry, uncertainty is even higher because the political institutions continue to be authoritarian. Therefore, whether the government has a strategic plan in the front-end phase is a basic premise of megaprojects (OECD 2017). Under this latent variable, the presence of a feasible strategic plan (SP11) and a dedicated procedure for governing the project (SP13) received the highest factor loadings (0.864 and 0.857 ). The government is supposed to allocate a budget to megaprojects within the limits of fiscal planning, decide how to deliver a project, and establish a process for generating a megaproject (Peterman et al., 2014). Otherwise, weak planning might hamper the operation and implementation of projects (Shrestha et al., 2017). Besides, proper solutions for relocation (SP15) had the lowest factor loading $(0.772)$ on the SP. On the one hand, this result may be related to the contradiction between rapid economic growth and backwardness of relocation compensation provisions. Relocation arrangement and expropriation compensation may easily cause conflicts (Shi et al., 2015). The government must guarantee reasonable compensation for relocation, to maintain social stability and maximize residents' benefit (Liu et al., 2016). On the other hand, parts of the sample projects did not involve resettlement issues and the respondents gave 1 point, which resulted the low factor loading. 
"Institutional design" (ID) was the sixth most critical component of governmental governance, with the lowest path coefficient of 0.130 . Since the governments have responsibilities in a broad array of areas, good institutional design is a precondition for governing megaproject just as previous studies indicating "a set of formal principle, structure and process is important in governing a project" (Mosavi, 2014). In the model, a clear set of documents of responsibilities (ID21) had the highest factor loading (0.854) on ID. This result is similar to that found in (Gunduz \& Yahya, 2018) who report scope and work definition contributes in finishing the project successfully. After the responsibilities settle down, coordination across the different levels of governments are needed to boost governance outcome (OECD, 2017). Besides, coordination exists not only within the governments, but also between government, the public and stakeholders. Formal coordination mechanisms (ID23) received the second highest outer loading (0.831) on ID. This is consistent with those of other studies that show formal communications such as meetings to be of great importance in buffering conflicts (Bygballe et al., 2015). Also, informal governance approaches appear to be a positive compliment, which in turn increases performance. In some megaprojects, personal relationship between stakeholders and governmental staffs offers convenience in solving problems (Chi et al., 2011). In the test, determine how to deliver the project (ID22) received the third factor loading (0.778) on ID. Delivery modalities vary under governmental decisions in balancing the political, sectoral, economic, and strategic aspects (Flyvbjerg et al., 2003; OECD, 2017). the government keeps its regularity position (Bennon et al., 2017). Regulated privatization, state-owned enterprises, concessions or PPPs, or a combination of these (Flyvbjerg et al., 2003) may be involved by approaches for delivering and managing megaprojects.

\section{Post-survey interviews}

The post-survey interviews were carried out with five representatives who worked in an ongoing megaproject named West Bund Media Port (WBMP in short) conducted in Shanghai, China. WBMP is an important pilot program in the "megaproject list" in Xuhui District Government as well as in City Government. It starts from 2014 and is expected to complete in the end of 2018. The whole project was divided into 9 blocks and six developers were invited to construct the aboveground buildings. To better understand the governmental governance strategies in the construction procedures, five interviewees were provided with a presentation of the results from questionnaires and asked to comment on them. They all confirmed that the findings were reasonable and gave some explanations for the governmental governance practices in WBMP project to help gain an in-depth understanding of the findings.

According to the interviewees, the strategic planning of WBMP was confirmed in 2012 in line with the 12th Five-Year Plan of City Shanghai. Municipal Government set up a Development Management Committee as the authority to strengthen capacities of all the governmental agencies involved and facilitate all the stakeholders. To be in charge of developing West Bund area on behalf of local government, a solely state-owned enterprise - Shanghai West Bund Development Group (WB Group), was also founded. The construction process was not only aligned with existing laws and regulations, but also with dedicated procedure set by Management Committee. One important responsibility of the Management Commit- 
tee is holding thematic conferences when conflicts or problems emerge. Talking about this issue, interviewees from the consultant and contractor said: "in most cases, the Management Committee can solve our problems quickly and efficiently". Inside the Management Committee, a specialized oversight body was created to apply strict procedures for monitoring construction progress to ensure that WBMP project was built on time and within budget. Besides the Committee, Megaproject Office in Xuhui District performs an important steering and oversight role with regard to WBMP, even when it isn't involved in its delivery. And the multi-level labour emulations, held by Megaproject Office during the construction process, inspired contractors and improve the WBMP performance.

In addition to the governmental strategies mentioned above, the interviewees highlighted the importance of public monitoring on WBMP project. As a political symbol, WBMP projects has drawn attention from the public. In the front-end phase, resident representatives living around were invited to participate in the planning. During the construction phase, progress reports were prepared regularly and open to public. The role and impact of e-government strategy, through which the interaction between public and government was delivered, were brought up and emphasized by the interviewees. For instance, online platforms have offered new opportunities for public participation. Last year, a safety rumor about WBMP showed up on Weibo, the Chinese version of Twitter. WB Group detected it quickly, reported to Megaproject Office, established a joint team to investigate the issue, and publicized the investigation progress timely. Also, both citizens and business communities can report the illegal behaviors via government websites or mayor's mailbox. Since fiscal year 2014, Xuhui Audit Bureau have engaged to exercise its surveillance and audit powers and no irregularities have been reported. Besides, as the project moves on, an evolving document about risk assessment is periodically reviewed and updated, which supports WBMP's ability to adapt to the evolving environment.

In general, referring to the governmental governance strategies mentioned by the interviewees, it could be noted that they are mainly associated with the planning, cooperation between levels of governments, regulatory oversight, public supervision, anti-corruption approaches and risk management, which are generally in accord with the findings obtained from the questionnaire survey. Thus, findings have proven to be reliable.

\section{Conclusions and policy recommendations}

This study investigated the impacts of adopting governmental governance on megaprojects performance and identified the critical components of governmental governance that can help improve megaproject performance. A theoretical hypothesis between governmental governance and megaproject performance were proposed and then verified using the approach of partial least squares structural equation modelling. Data collected from 239 professionals in the megaproject sector of China were analyzed. Results reported that governmental governance can contribute to improving megaproject performance. It also revealed that "public monitoring and scrutiny" was the most critical latent variable of governmental governance on megaproject performance, followed by "systemic risk management", "regulatory oversight", "construction of clean government", "strategic planning", and "institutional design". 
It is the first research effort to develop a unique framework of governmental governance of megaproject. It highlights governance practices of government, identifies the most critical practices that governments should adopt to facilitate the provision of megaprojects, and reveals positive impacts of governmental governance on megaproject performance. This study extends the governance framework in megaprojects and thus contributes to the current body of knowledge. Additionally, it can enhance the practitioners' understandings of governmental governance and thereby benefitting the practice.

The findings of this study can offer policy recommendations for the design of governmental governance systems. According to PLS-SEM results, public monitoring and scrutiny had the highest path coefficient. Thus, government agencies should try to maximize public participant into their governance systems and institutionalize participation mechanisms and practices. For instance, the government should hold public hearings to obtain public comments on megaprojects, provide online platforms where the public can access megaproject information, and establish channels for the public to raise their concerns. Additionally, the findings recommended that the government should take actions to reduce corruption. Effective strategies include but are not limited to inviting private investment and increasing the transparency in the implementation of megaprojects.

\section{Limitations and future research}

Findings of this study are subject to some limitations needed to be considered in future research. First, this study collected opinion-based data from respondents and bias might occur due to the different backgrounds of the respondents. Second, the sample size of the questionnaire was relatively small to a study that adopted structural equation modelling approach. These results therefore need to be interpreted with caution. Third, the unique political and cultural context in China impedes the generalization of the findings to other countries and regions. It might be possible to extrapolate to a government-led context similar as China, but when it comes to others, contextual factors, such as the political system, tendering practices, and social factors, must be taken into consideration.

As for future research, it is necessary to develop an evaluation model to assess the maturity of adopting governmental governance in megaprojects. Additionally, further studies could also be conducted to compare the adoption of governmental governance between different countries, so that the body of knowledge of governmental governance could be further established. Lastly, an effectiveness comparison for adopting different governance mechanisms (e.g., governmental, contractual, and relational governance) could also be conducted to identify the most effective governance mechanism.

\section{Funding}

This work was supported by the National Natural Science Foundation of China (Grant Nos 71390523 and 71901224), and Central South University (Grant No. 202045013). 


\section{Author contributions}

Zhao ZHAI was responsible for data collection, data analysis, and manuscript draft. Ming SHAN conceived the study and was responsible for data analysis and data interpretation. Yun LE conceived the study.

\section{Disclosure statement}

This study has no competing financial, professional, or personal interests from other parties.

\section{References}

Aarseth, W., Ahola, T., Aaltonen, K., Økland, A., \& Andersen, B. (2017). Project sustainability strategies: A systematic literature review. International Journal of Project Management, 35(6), 1071-1083. https://doi.org/10.1016/j.ijproman.2016.11.006

Abowitz, D. A., \& Toole, T. M. (2010). Mixed method research: fundamental issues of design, validity, and reliability in construction research. Journal of Construction Engineering and Management, 136(1), 108-116. https://doi.org/10.1061/(ASCE)CO.1943-7862.0000026

Arnstein, S. (1969). A ladder of citizen participation. Journal of the American Planning Association, 35(4), 216-224. https://doi.org/10.1080/01944366908977225

Aubry, M., Richer, M.-C., \& Lavoie-Tremblay, M. (2014). Governance performance in complex environment: The case of a major transformation in a university hospital. International Journal of Project Management, 32(8), 1333-1345. https://doi.org/10.1016/j.ijproman.2013.07.008

Bednar, M. K. (2012). Watchdog or lapdog? A behavioral view of the media as a corporate governance mechanism. Academy of Management Journal, 55(1), 131-150. https://doi.org/10.5465/amj.2009.0862

Bennon, M., Kim, M. J., \& Levitt, R. E. (2017). US infrastructure gap(s): federal policy and local public institutions. https://doi.org/10.2139/ssrn.3036650

Besfamille, M. (2004). Collusion in local public works. International Economic Review, 45(4), 1193 1219. https://doi.org/10.1111/j.0020-6598.2004.00302.x

Biesenthal, C., \& Wilden, R. (2014). Multi-level project governance: Trends and opportunities. International Journal of Project Management, 32(8), 1291-1308. https://doi.org/10.1016/j.ijproman.2014.06.005

Bozza, A., Asprone, D., \& Fabbrocino, F. (2017). Urban resilience: a civil engineering perspective. Sustainability, 9(103). https://doi.org/10.3390/su9010103

Brunet, M., \& Aubry, M. (2016). The three dimensions of a governance framework for major public projects. International Journal of Project Management, 34(8), 1596-1607. https://doi.org/10.1016/j.ijproman.2016.09.004

Bygballe, L. E., Dewulf, G., \& Levitt, R. E. (2015). The interplay between formal and informal contracting in integrated project delivery. Engineering Project Organization Journal, 5(1), 22-35. https://doi.org/10.1080/21573727.2014.992014

Callegari, C., Szklo, A., \& Schaeffer, R. (2018). Cost overruns and delays in energy megaprojects: How big is big enough? Energy Policy, 114, 211-220. https://doi.org/10.1016/j.enpol.2017.11.059

Cardenas, I. C., Voordijk, H., \& Dewulf, G. (2017). Beyond theory: Towards a probabilistic causation model to support project governance in infrastructure projects. International Journal of Project Management, 35(3), 432-450. https://doi.org/10.1016/j.ijproman.2017.01.002 
Chen, G.-X., Shan, M., Chan, A. P. C., Liu, X., \& Zhao, Y.-Q. (2019). Investigating the causes of delay in grain bin construction projects: the case of China. International Journal of Construction Management, 19(1), 1-14. https://doi.org/10.1080/15623599.2017.1354514

Chen, L., \& Manley, K. (2014). Validation of an instrument to measure governance and performance on collaborative infrastructure projects. Journal of Construction Engineering and Management, 140(5). https://doi.org/10.1061/(ASCE)CO.1943-7862.0000834

Chi, C. S., Ruuska, I., Levitt, R., Ahola, T., \& Artto, K. (2011, August 9-11). A relational governance approach for megaprojects: case studies of Beijing T3 and bird's nest projects in China. In Engineering Project Organizations Conference, Estes Park, Colorado.

Crawford, L., \& Helm, J. (2009). Government and governance: The value of project management in the public sector. Project Management Journal, 40(1), 73-87. https://doi.org/10.1002/pmj.20107

Dickson, B. J., Landry, P. F., Shen, M., \& Yan, J. (2016). Public goods and regime support in urban China. The China Quarterly, 228, 859-880. https://doi.org/10.1017/S0305741016001156

Di Maddaloni, F., \& Davis, K. (2017). The influence of local community stakeholders in megaprojects: Rethinking their inclusiveness to improve project performance. International Journal of Project Management, 35(8), 1537-1556. https://doi.org/10.1016/j.ijproman.2017.08.011

Eriksson, P. E., \& Westerberg, M. (2011). Effects of cooperative procurement procedures on construction project performance: A conceptual framework. International Journal of Project Management, 29(2), 197-208. https://doi.org/10.1016/j.ijproman.2010.01.003

Flyvbjerg, B. (2011). Over budget, over time, over and over again: Managing major projects. In P. W. G. Morris, J. K. Pinto, \& J. Söderlund (Eds.), The Oxford Handbook of Project Management (pp. 321-344). Oxford University Press. https://doi.org/10.1093/oxfordhb/9780199563142.003.0014

Flyvbjerg, B., Bruzelius, N., \& Rothengatter, W. (2003). Megaprojects and risk: An anatomy of ambition: Cambridge University Press. https://doi.org/10.1017/CBO9781107050891

Flyvbjerg, B., Hon, C.-k., \& Fok, W. H. (2016). Reference class forecasting for Hong Kong's major roadworks projects. Proceedings of the Institution of Civil Engineers - Civil Engineering, 169(6), 17-24. https://doi.org/10.1680/jcien.15.00075

Flyvbjerg, B. (2014). What you should know about megaprojects and why: An overview. Project Management Journal, 45(2), 6-19. https://doi.org/10.1002/pmj.21409

Ghosh, S., Buckler, L., Skibniewski, M. J., Negahban, S., \& Kwak, Y. H. (2014). Organizational governance to integrate sustainability projects: a case study. Technological and Economic Development of Economy, 20(1), 1-24. https://doi.org/10.3846/20294913.2014.850755

Gil, N., \& Lundrigan, C. (2012). The leadership and governance of megaprojects (CID Technical Report No. 3/2012). https://personalpages.manchester.ac.uk/staff/nuno.gil/Technical\%20reports/CID\%20 Technical\%20Report\%20No3\%20Leadership\%20and\%20Governance\%20April\%202012.pdf

Grubbauer, M., \& Čamprag, N. (2018). Urban megaprojects, nation-state politics and regulatory capitalism in Central and Eastern Europe: The Belgrade Waterfront project. Urban Studies, 56(4), 649-671. https://doi.org/10.1177/0042098018757663

Gunduz, M., \& Yahya, A. M. A. (2018). Analysis of project success factors in construction industry. Technological and Economic Development of Economy, 24(1), 67-80. https://doi.org/10.3846/20294913.2015.1074129

Hair, J. F., Ringle, C. M., \& Sarstedt, M. (2011). PLS-SEM: Indeed a silver bullet. Journal of Marketing theory and Practice, 19(2), 139-152. https://doi.org/10.2753/MTP1069-6679190202

Hanna, A. S., Lotfallah, W., Aoun, D. G., \& Asmar, M. E. (2014). Mathematical formulation of the project quarterback rating: new framework to assess construction project performance. Journal of Construction Engineering and Management, 140(8).

https://doi.org/10.1061/(ASCE)CO.1943-7862.0000871 
Haveman, H. A., Jia, N., Shi, J., \& Wang, Y. (2017). The dynamics of political embeddedness in China. Administrative Science Quarterly, 62(1), 67-104. https://doi.org/10.1177/0001839216657311

$\mathrm{Hu}$, Y., Chan, A. P., Le, Y., Xu, Y., \& Shan, M. (2016). Developing a program organization performance index for delivering construction megaprojects in China: Fuzzy synthetic evaluation analysis. Journal of Management in Engineering, 32(4), 05016007. https://doi.org/10.1061/(ASCE)ME.1943-5479.0000432

Hu, Y., Le, Y., Gao, X. L., Li, Y. K., \& Liu, M. Q. (2018). Grasping institutional complexity in infrastructure mega-projects through the multi-level governance system: A case study of the Hong KongZhuhai-Macao Bridge construction. Frontiers of Engineering Management, 5(1), 52-63. https://doi.org/10.15302/J-FEM-2018074

Hwang, B.-G., Shan, M., \& Looi, K.-Y. (2018a). Key constraints and mitigation strategies for prefabricated prefinished volumetric construction. Journal of Cleaner Production, 183, 183-193. https://doi.org/10.1016/j.jclepro.2018.02.136

Hwang, B.-G., Shan, M., \& Phuah, S. L. (2018b). Safety in green building construction projects in Singapore: Performance, critical issues, and improvement solutions. KSCE Journal of Civil Engineering, 22(2), 447-458. https://doi.org/10.1007/s12205-017-1961-3

Jackson, S., \& Sleigh, A. (2000). Resettlement for China's Three Gorges Dam: socio-economic impact and institutional tensions. Communist and Post-Communist Studies, 33(2), 223-241. https://doi.org/10.1016/S0967-067X(00)00005-2

Joslin, R., \& Müller, R. (2016). The relationship between project governance and project success. International Journal of Project Management, 34(4), 613-626. https://doi.org/10.1016/j.ijproman.2016.01.008

Klakegg, O. J., Williams, T., Magnussen, O. M., \& Glasspool, H. (2008). Governance frameworks for public project development and estimation. Project Management Journal, 39, S27-S42. https://doi.org/10.1002/pmj.20058

Klakegg, O. J., Williams, T., \& Shiferaw, A. T. (2016). Taming the 'trolls': Major public projects in the making. International Journal of Project Management, 34(2), 282-296. https://doi.org/10.1016/j.ijproman.2015.03.008

Le, Y., Shan, M., Chan, A. P. C., \& Hu, Y. (2014). Investigating the causal relationships between causes of and vulnerabilities to corruption in the Chinese public construction sector. Journal of Construction Engineering and Management, 140(9), 0501400701-0501400712. https://doi.org/10.1061/(ASCE)CO.1943-7862.0000886

Li, T. H. Y., Ng, S. T., \& Skitmore, M. (2016). Modeling multi-stakeholder multi-objective decisions during public participation in major infrastructure and construction projects: a decision rule approach. Journal of Construction Engineering and Management, 142(3), 04015087. https://doi.org/10.1061/(ASCE)CO.1943-7862.0001066

Li, Y. K., Han, Y., Luo, M., \& Zhang, Y. (2019). Impact of megaproject governance on project performance: dynamic governance of the Nanning transportation hub in China. Journal of Management in Engineering, 35(3), 05019002. https://doi.org/10.1061/(ASCE)ME.1943-5479.0000681

Li, Y. K., Lu, Y. J., Ma, L., \& Kwak, Y. H. (2018). Evolutionary governance for mega-event projects (MEPs): a case study of the World Expo 2010 in China. Project Management Journal, 49(1), 57-78. https://doi.org/10.1177/875697281804900105

Lin, H., Sui, Y., Ma, H., Wang, L., \& Zeng, S. (2018). CEO narcissism, public concern, and megaproject social responsibility: moderated mediating examination. Journal of Management in Engineering, 34(4). https://doi.org/10.1061/(ASCE)ME.1943-5479.0000629

Lin, H., Zeng, S., Ma, H., Zeng, R., \& Tam, V. W. Y. (2017). An indicator system for evaluating megaproject social responsibility. International Journal of Project Management, 35(7), 1415-1426. https://doi.org/10.1016/j.ijproman.2017.04.009 
Lin, H., Zeng, S. X., Ma, H. Y., \& Chen, H. Q. (2015). How political connections affect corporate environmental performance: the mediating role of green subsidies. Human and Ecological Risk Assessment, 21(8), 2192-2212. https://doi.org/10.1080/10807039.2015.1044937

Ling, F. Y. Y., Low, S. P., Wang, S. Q., \& Lim, H. H. (2009). Key project management practices affecting Singaporean firms' project performance in China. International Journal of Project Management, 27(1), 59-71. https://doi.org/10.1016/j.ijproman.2007.10.004

Liu, J., Zhao, X., \& Li, Y. (2017). Exploring the factors inducing contractors' unethical behavior: case of China. Journal of Professional Issues in Engineering Education and Practice, 143(3). https://doi.org/10.1061/(ASCE)EI.1943-5541.0000316

Liu, Z., Zhu, Z., Wang, H., \& Huang, J. (2016). Handling social risks in government-driven mega project: An empirical case study from West China. International Journal of Project Management, 34(2), 202-218. https://doi.org/10.1016/j.ijproman.2015.11.003

Locatelli, G., Mariani, G., Sainati, T., \& Greco, M. (2017). Corruption in public projects and megaprojects: There is an elephant in the room! International Journal of Project Management, 35(3), 252-268. https://doi.org/10.1016/j.ijproman.2016.09.010

Locatelli, G., Palerma, E., \& Mancini, M. (2015). Assessing the economics of large Energy Storage Plants with an optimisation methodology. Energy, 83, 15-28. https://doi.org/10.1016/j.energy.2015.01.050

Lu, Y. J., Li, Y. K., Pang, D., \& Zhang, Y. X. (2015). Organizational network evolution and governance strategies in megaprojects. Construction Economics and Building, 15(3), 19-33. https://doi.org/10.5130/AJCEB.v15i3.4609

Ma, H. Y., Zeng, S. X., Lin, H., Chen, H. Q., \& Shi, J. J. (2017). The societal governance of megaproject social responsibility. International Journal of Project Management, 35(7), 1365-1377. https://doi.org/10.1016/j.ijproman.2017.01.012

Morris, P. W. G., \& Geraldi, J. (2011). Managing the institutional context for projects. Project Management Journal, 42(6), 20-32. https://doi.org/10.1002/pmj.20271

Mosavi, A. (2014). Exploring the roles of portfolio steering committees in project portfolio governance. International Journal of Project Management, 32(3), 388-399.

https://doi.org/10.1016/j.ijproman.2013.07.004

Müller, R., \& Lecoeuvre, L. (2014). Operationalizing governance categories of projects. International Journal of Project Management, 32(8), 1346-1357. https://doi.org/10.1016/j.ijproman.2014.04.005

Ng, S. T., Li, T. H. Y., \& Wong, J. M. W. (2012). Rethinking public participation in infrastructure projects. Proceedings of the Institution of Civil Engineers - Municipal Engineer, 165(2), 101-113. https://doi.org/10.1680/muen.11.00027

OECD. (2016). Integrity framework for public investment. OECD Public Governance Reviews. OECD Publishing. https://doi.org/10.1787/9789264251762-en

OECD. (2017). Getting infrastructure right: a framework for better governance. OECD Publishing. https://doi.org/10.1787/9789264272453-en

Papke-Shields, K. E., \& Boyer-Wright, K. M. (2017). Strategic planning characteristics applied to project management. International Journal of Project Management, 35(2), 169-179. https://doi.org/10.1016/j.ijproman.2016.10.015

Partidário, M. R., \& Coutinho, M. (2011). The Lisbon new international airport: The story of a decisionmaking process and the role of Strategic Environmental Assessment. Environmental Impact Assessment Review, 31(3), 360-367. https://doi.org/10.1016/j.eiar.2010.12.002

Peterman, A., Kourula, A., \& Levitt, R. (2014). Balancing act: Government roles in an energy conservation network. Research Policy, 43(6), 1067-1082. https://doi.org/10.1016/j.respol.2013.12.007

Pinto, J. K., Slevin, D. P., \& English, B. (2009). Trust in projects: An empirical assessment of owner/ contractor relationships. International Journal of Project Management, 27(6), 638-648.

https://doi.org/10.1016/j.ijproman.2008.09.010 
Pitsis, T. S., Sankaran, S., Gudergan, S., \& Clegg, S. R. (2014). Governing projects under complexity: theory and practice in project management. International Journal of Project Management, 32(8), 1285-1290. https://doi.org/10.1016/j.ijproman.2014.09.001

Ren, X. (2017). Biggest infrastructure bubble ever? In B. Flyvbjerg (Ed.), The Oxford handbook of megaproject management (pp. 137-154). Oxford University Press.

https://doi.org/10.1093/oxfordhb/9780198732242.013.6

Sallinen, L., Ahola, T., \& Ruuska, I. (2011). Governmental stakeholder and project owner's views on the regulative framework in nuclear projects. Project Management Journal, 42(6), 33-47. https://doi.org/10.1002/pmj.20270

Sallinen, L., Ruuska, I., \& Ahola, T. (2013). How governmental stakeholders influence large projects: the case of nuclear power plant projects. International Journal of Managing Projects in Business, 6(1), 51-68. https://doi.org/10.1108/17538371311291026

Shan, M., Chan, A. P., Le, Y., \& Hu, Y. (2015a). Investigating the effectiveness of response strategies for vulnerabilities to corruption in the Chinese public construction sector. Science and Engineering Ethics, 21(3), 683-705. https://doi.org/10.1007/s11948-014-9560-x

Shan, M., Chan, A. P. C., Le, Y., Xia, B., \& Hu, Y. (2015b). Measuring corruption in public construction projects in China. Journal of Professional Issues in Engineering Education and Practice, 141(4), 05015001. https://doi.org/10.1061/(ASCE)EI.1943-5541.0000241

Shan, M., Le, Y., Yiu, K. T., Chan, A. P., \& Hu, Y. (2017). Investigating the underlying factors of corruption in the public construction sector: Evidence from China. Science and Engineering Ethics, 23(6), 1643-1666. https://doi.org/10.1007/s11948-016-9865-z

Shenhar, A., \& Holzmann, V. (2017). The three secrets of megaproject success: clear strategic vision, total alignment, and adapting to complexity. Project Management Journal, 48(6), 29-46. https://doi.org/10.1177/875697281704800604

Shi, Q., Liu, Y., Zuo, J., Pan, N. X., \& Ma, G. F. (2015). On the management of social risks of hydraulic infrastructure projects in China: A case study. International Journal of Project Management, 33(3), 483-496. https://doi.org/10.1016/j.ijproman.2014.06.003

Shiferaw, A. T., Klakegg, O. J., \& Haavaldsen, T. (2012). Governance of public investment projects in Ethiopia. Project Management Journal, 43(4), 52-69. https://doi.org/10.1002/pmj.21280

Shrestha, A., Chan, T.-K., Aibinu, A. A., Chen, C., \& Martek, I. (2017). Risks in PPP water projects in China: Perspective of local governments. Journal of Construction Engineering and Management, 143(7), 05017006. https://doi.org/10.1061/(ASCE)CO.1943-7862.0001313

Söderlund, J., Sankaran, S., \& Biesenthal, C. (2017). The past and present of megaprojects. Project Management Journal, 48(6), 5-16. https://doi.org/10.1177/875697281704800602

Stoney, C., \& Krawchenko, T. (2012). Transparency and accountability in infrastructure stimulus spending: A comparison of Canadian, Australian and U.S. programs. Canadian Public Administration-Administration Publique Du Canada, 55(4), 481-503. https://doi.org/10.1111/j.1754-7121.2012.00235.x

Toivonen, A., \& Toivonen, P. U. (2014). The transformative effect of top management governance choices on project team identity and relationship with the organization - An agency and stewardship approach. International Journal of Project Management, 32(8), 1358-1370.

https://doi.org/10.1016/j.ijproman.2014.07.001

Too, E. G., \& Weaver, P. (2014). The management of project management: A conceptual framework for project governance. International Journal of Project Management, 32(8), 1382-1394.

https://doi.org/10.1016/j.ijproman.2013.07.006

Toor, S.-u.-R., \& Ogunlana, S. O. (2010). Beyond the 'iron triangle': Stakeholder perception of key performance indicators (KPIs) for large-scale public sector development projects. International Journal of Project Management, 28(3), 228-236. https://doi.org/10.1016/j.ijproman.2009.05.005 
Tung, R. L. (1981). Patterns of motivation in Chinese industrial enterprises. Academy of Management Review, 6(3), 481-489. https://doi.org/10.5465/amr.1981.4285792

Ul Haq, S., Liang, C. Y., Gu, D. X., Du, J. T., \& Zhao, S. P. (2018). Project governance, project performance, and the mediating role of project quality and project management risk: an agency theory perspective. Engineering Management Journal, 30(4), 274-292.

https://doi.org/10.1080/10429247.2018.1503038

ul Musawir, A., Serra, C. E. M., Zwikael, O., \& Ali, I. (2017). Project governance, benefit management, and project success: Towards a framework for supporting organizational strategy implementation. International Journal of Project Management, 35(8), 1658-1672.

https://doi.org/10.1016/j.ijproman.2017.07.007

Vahanvati, M., \& Mulligan, M. (2017). A new model for effective post-disaster housing reconstruction: Lessons from Gujarat and Bihar in India. International Journal of Project Management, 35(5), 802-817. https://doi.org/10.1016/j.ijproman.2017.02.002

van Marrewijk, A., \& Smits, K. (2016). Cultural practices of governance in the Panama Canal Expansion Megaproject. International Journal of Project Management, 34(3), 533-544.

https://doi.org/10.1016/j.ijproman.2015.07.004

Wang, P. (2014). Government intervention and the empowerment process: Citizen involvement in the 2010 Shanghai World Expo. Journal of Public Affairs, 14(2), 1479-1854.

https://doi.org/10.1002/pa.1517

Wetzels, M., Odekerken-Schröder, G., \& Van Oppen, C. (2009). Using PLS path modeling for assessing hierarchical construct models: Guidelines and empirical illustration. Mis Quarterly, 33(1), 177-195. https://doi.org/10.2307/20650284

World Bank. (2016). A framework for disclosure in Public-Private Partnerships. http://pubdocs.worldbank.org/en/773541448296707678/Disclosure-in-PPPs-Framework.pdf

Xie, L., Xia, B., Hu, Y., Shan, M., Le, Y., \& Chan, A. P. (2017). Public participation performance in public construction projects of South China: A case study of the Guangzhou Games venues construction. International Journal of Project Management, 35(7), 1391-1401.

https://doi.org/10.1016/j.ijproman.2017.04.003

Zhai, Z., Ahola, T., Le, Y., \& Xie, J. (2017). Governmental governance of megaprojects: The case of Expo 2010 Shanghai. Project Management Journal, 48(1), 37-50. https://doi.org/10.1177/875697281704800103

Zhang, B., Le, Y., Xia, B., \& Skitmore, M. (2017). Causes of business-to-government corruption in the tendering process in China. Journal of Management in Engineering, 33(2).

https://doi.org/10.1061/(ASCE)ME.1943-5479.0000479

Zhang, Y., Gu, J., Shan, M., Xiao, Y., \& Darko, A. (2018). Investigating private sectors' behavioral intention to participate in PPP projects: An empirical examination based on the theory of planned behavior. Sustainability, 10(8), 2692. https://doi.org/10.3390/su10082692

Zhao, X., \& Singhaputtangkul, N. (2016). Effects of firm characteristics on enterprise risk management: Case study of Chinese construction firms operating in Singapore. Journal of Management in Engineering, 32(4). https://doi.org/10.1061/(ASCE)ME.1943-5479.0000434

Zhao, X., Wu, P., \& Wang, X. (2018). Risk paths in BIM adoption: empirical study of China. Engineering, Construction and Architectural Management, 25(9), 1170-1187. https://doi.org/10.1108/ECAM-08-2017-0169

Zhu, Y. L., Shi, Q. Q., Li, Q., \& Yin, Z. M. (2018). Decision-making governance for the Hong KongZhuhai-Macao Bridge in China. Frontiers of Engineering Management, 5(1), 30-39. https://doi.org/10.15302/J-FEM-2018087

Zwikael, O., \& Smyrk, J. (2015). Project governance: Balancing control and trust in dealing with risk. International Journal of Project Management, 33(4), 852-862.

https://doi.org/10.1016/j.ijproman.2014.10.012 